\title{
Hubungan Pengetahuan dengan Keikutsertaan Wanita Usia Subur (WUS) dalam Pemeriksaan IVA
}

\author{
Misrina Retnowati , Naomi Pramila \\ Email: rinaasya7608@gmail.com \\ D-III Kebidanan, Akademi Kebidanan Graha Mandiri Cilacap, Indonesia \\ Jl. Dr.Soetomo No. 4B Cilacap \\ Telp. (0282) 534908
}

\begin{abstract}
Abstrak
Kanker merupakan salah satu penyakit tidak menular yang telah menjadi masalah kesehatan di dunia, termasuk di Indonesia.Angka kematian yang tinggi dari kanker serviks secara global dapat dikurangi dengan deteksi dini melalui pemeriksaan IVA. Masih tingginya angka penderita kanker serviks di Indonesia disebabkan oleh rendahnya motivasi WUS untuk melakukan pemeriksaan IVA, didasari oleh pengetahuan WUS tentang pemeriksaan IVA. Penelitian ini bertujuan untuk mengetahui hubungan pengetahuan dengan keikutsertaan wanita usia subur dalam pemeriksaan IVA di Desa Pangebatan. Jenis penelitian ini adalah penelitian survey analitik dengan menggunakan pendekatan cross sectional. Popuasi dalam penelitian ini adalah semua Wanita Usia Subur (WUS) di Desa Pangebatan sebanyak 851 orang. Sampel dalam penelitian ini sebanyak 90 orang diambil dengan Teknik proporsional random sampling. Analisis univariat menggunakan distribusi frekuensi dan analisis bivariat menggunakan uji Chi Square. Hasil penelitian menunjukkan bahwa pengetahuan WUS tentang kanker serviks sebagian besar baik sebanyak 48 orang $(53,3 \%)$ dan WUS sebagian besar tidak mengikuti pemeriksaan IVA sebanyak 56 orang $(62,2 \%)$. Hasil analisis bivariat dengan menggunakan uji chi square diperoleh nilai $p=0,010$ yang artinya ada hubungan pengetahuan dengan keikutsertaan WUS dalam pemeriksaan IVA. Kesimpulannya ada hubungan antara pengetahuan dengan keikutsertaan wanita usia subur dalam pemeriksaan IVA di Desa Pangebatan.
\end{abstract}

Kata Kunci: pengetahuan; keikutsertaan dalam pemeriksaan iva.

\begin{abstract}
Cancer is a non-communicable disease that has become a health problem in the world, including in Indonesia. The high mortality rate from cervical cancer globally can be reduced by early detection through IVA testing. The high number of cervical cancer sufferers in Indonesia is due to the low motivation of WUS to perform IVA examinations, based on WUS 'knowledge of IVA examinations. This study aims to determine the relationship between knowledge and participation of women of childbearing age in IVA examinations in Pangebat Village. This type of research is an analytical survey research using a cross sectional approach. The population in this study were all women of fertile age (WUS) in Pangebat village as many as 851 people. The sample in this study as many as 90 people were taken by proportional random sampling technique. Univariate analysis using frequency distribution and bivariate analysis using Chi Square test. The results showed that knowledge of WUS about cervical cancer was mostly good as many as 48 people $(53.3 \%)$ and most of them did not follow IVA examination as many as 56 people $(62.2 \%)$. The results of bivariate analysis using the chi square test obtained $\mathrm{p}$ value $=0.010$, which means that there is a relationship between knowledge and participation of WUS in the IVA examination. The conclusion is that there is a relationship between knowledge and the participation of women of childbearing age in IVA examinations in Pangebat Village
\end{abstract}

Keywords: knowledge; participation in the iva examination. 
Jurnal Kebidanan Harapan Ibu Pekalongan

\section{Pendahuluan}

Kanker merupakan salah satu penyakit tidak menular yang telah menjadi masalah kesehatan di dunia, termasuk di Indonesia. Berdasarkan data WHO kanker serviks atau kanker leher rahim adalah salah satu kanker yang paling banyak didiagnosis pada wanita diseluruh dunia dengan perkiraan 570.000 kasus baru pada tahun 2018 mewakili $6,6 \%$ dari semua kanker wanita. Berdasarkan Profil Kesehatan Provinsi Jawa Tengah tahun 2018, yang melakukan deteksi dini kanker serviks melalui pemeriksaan IVA triwulan 3 yaitu sebanyak 29.841 orang dengan hasil IVA positif 2.243 orang. ${ }^{(1)}$

Risiko terkena kanker serviks meningkat dengan bertambahnya usia dan umumnya antara usia 30 hingga 50 tahun. Insiden kanker di Indonesia masih belum diketahui secara pasti, karena belum ada registrasi kanker berbasis populasi yang dilaksanakan. Berdasarkan data Globocan, IARC (International Agency for Research on Cancer) 2002, didapatkan estimasi insiden kanker serviks sebesar 16 per 100.000 perempuan. Badan Registrasi Kanker Ikatan Dokter Ahli Patologi Indonesia (IAPI) di 13 Rumah Sakit di Indonesia menunjukkan, kanker serviks menduduki peringkat pertama dari seluruh kasus kanker sebesar $17,2 \%$ diikuti kanker payudara 12,2 $\%$. ${ }^{(2)}$

Insiden kanker serviks dapat ditekan dengan melakukan upaya pencegahan primer dan diikuti dengan pencegahan sekunder seperti meningkatkan kegiatan penyuluhan dan pendidikan kesehatan kepada masyarakat untuk menjalankan pola hidup sehat, menghindari faktor risiko terkena kanker, melakukan imunisasi dengan vaksin HPV (Human Papilloma Virus) dan diikuti dengan deteksi dini kanker serviks melalui pemeriksaan IVA (Inspeksi Visual Asam Asetat) dan Pap Smear. ${ }^{(3)}$

Metode IVA merupakan salah satu metode yang efektif dan efisien untuk mendeteksi dini kanker serviks. Setiap wanita usia subur (WUS) hendaknya termotivasi untuk melakukan tes IVA. Dorongan WUS untuk mengikuti pemeriksaan IVA untuk mendeteksi dini terjadinya kanker serviks dapat dipengaruhi oleh faktor internal, diantaranya faktor pengetahuan. Pengetahuan tentang kanker serviks penting untuk dimiliki oleh setiap wanita usia subur agar memiliki kemauan dan kesadaran untuk melakukan upaya pencegahan. Perilaku seseorang yang didasari dengan pengetahuan sifatnya lebih menetap. Pengetahuan yang baik dari WUS tentang kanker servik diharapkan dapat melandasi sikap dan mendorong tindakannya untuk melakukan pencegahan kanker servik. ${ }^{(4)}$

Cakupan IVA di Indonesia sampai dengan tahun 2016 sebesar $4,34 \%$ yang masih jauh dari target nasional yaitu $10 \%$. Berdasarkan hasil studi pendahuluan yang dilakukan di Puskesmas Karanglewas tahun 2018, untuk Desa Pangebatan yang melakukan pemeriksaan IVA sebanyak 81 orang dari jumlah total WUS 851 orang. Berdasarkan uraian diatas, peneliti tertarik untuk melakukan penelitian tentang hubungan pengetahuan dengan keikutsertaan wanita usia subur (WUS) dalam pemeriksaan IVA di Desa Pangebatan. 
Jurnal Kebidanan Harapan Ibu Pekalongan

\section{MetodePenelitian}

Penelitian ini adalah penelitian survey analitik dengan menggunakan pendekatan cross sectional. Dalam peneilitian ini digunakan untuk mengetahui hubungan pengetahuan dengan keikutsertaan Wanita Usia Subur (WUS) dalam pemeriksaan IVA di Desa Pangebatan Kecamatan Karanglewas.

Populasi dalam penelitian ini adalah semua Wanita Usia Subur (WUS) di Desa Pangebatan tahun 2018 sebanyak 851 orang. Sampel dalam penelitian ini sebanyak 90 orang diambil dengan Teknik proporyional random sampling. Analisis data terdiri dari analisis univariat dan analisis bivariat. Analisis univariat menggunakan distribusi rekuensi dan analisis bivariat menggunakan uji Chi Square. ${ }^{(5)}$

\section{Hasil dan Pembahasan} Analisis Univariat

Diagram 1. Distribusi Frekuensi Pengetahuan WUS tentang kanker serviks

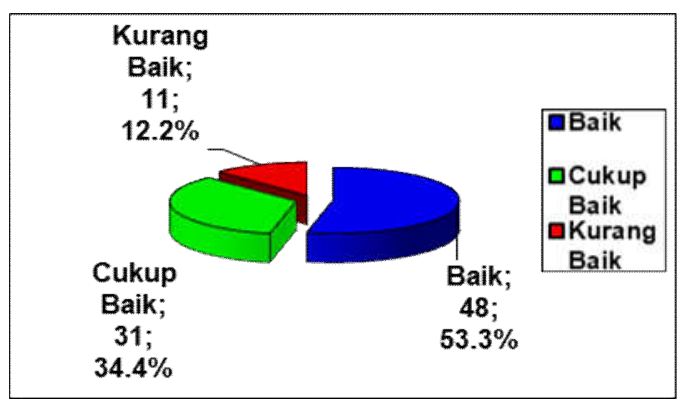

Berdasarkan diagram 1 di atas dapat diketahui bahwa pengetahuan WUS tentang kanker serviks di Desa Pangebatan sebagian besar baik sebanyak 48 orang $(53,3 \%)$ dan sebagian kecil kurang baik sebanyak 11 orang $(12,2 \%)$.

Pengetahuan menurut Soekanto, merupakan pesan kesan di dalam pikiran manusia sebagai hasil penggunaan panca inderanya yang berbeda sekali dengan kepercayaan
(Beliefs), takhayul (Supercitition) dan penerangan-penerangan yang keliru (Misinformation). ${ }^{(6)}$

Teori Muzakkir, juga mendukung hasil penelitian yaitu semakin tinggi tingkat pendidikan seseorang, semakin mudah menerima informasi sehingga semakin banyak pula menerima pengetahuan yang dimilikinya dan jika tingkat pendidikan rendah, maka akan menghambat tingkat pengetahuan seseorang. ${ }^{(10)}$ Menurut Mubarak, menyatakan bahwa pendidikan merupakan bimbingan yang diberikan seseorang kepada orang lain terhadap suatu hal agar dapat memahami. Pendidikan akan membuat seseorang ingin tahu, mencari pengalaman dan memahami suatu informasi dengan baik sehingga informasi yang diterima akan menjadi pengetahuan yang baik. ${ }^{(11)}$

Pengetahuan tentang kanker serviks penting untuk dimiliki oleh setiap wanita usia subur agar memiliki kemauan dan kesadaran untuk melakukan upaya pencegahan. Perilaku seseorang yang didasari dengan pengetahuan sifatnya lebih menetap. Pengetahuan yang baik dari WUS tentang kanker servik diharapkan dapat melandasi sikap dan mendorong tindakannya untuk melakukan pencegahan kanker servik. $^{(4)}$

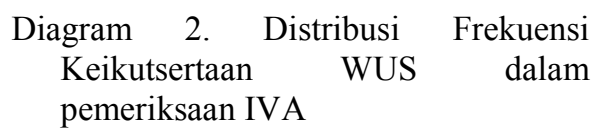

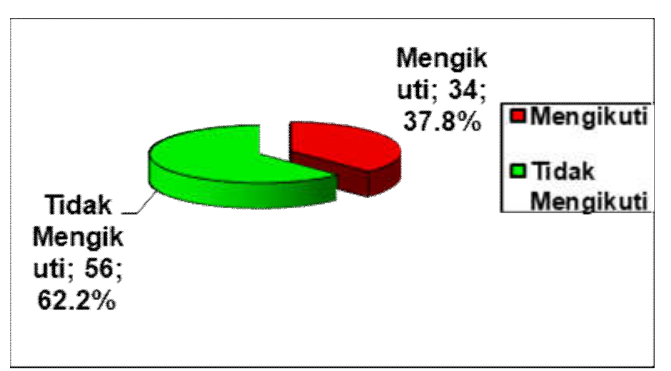


Berdasarkan diagram 2 di atas dapat diketahui bahwa WUS di Desa Pangebatan sebagian besar tidak mengikuti pemeriksaan IVA sebanyak 56 orang $(62,2 \%)$ dan sebagian kecil mengikuti pemeriksaan IVA sebanyak 34 orang $(37,8 \%)$.

Keikutsertaan WUS dalam pemeriksaan IVA sangat diperlukan, agar WUS dapat memantau kesehatannya, terutama dalam mencegah terjadinya kanker serviks. Masih banyaknya WUS yang belum mengikuti pemeriksaan, harus mendapatkan perhatian yang lebih dari tenaga kesehatan.

Kanker serviks adalah kanker yang menyerang servik (leher rahim), yakni daerah yang merupakan pintu masuk kearah rahim yang terletak antara rahim dan vagina. Kanker servik terdiri dari sel-sel tubuh yang tumbuh dengan jauh lebih cepat, yang tumbuh tidak teratur dan tidak terkendali, serta mendesak kesekitarnya dan menyusup ketempat yang lebih jauh. ${ }^{(7)}$

\section{Analisisbivariat}

Tabel 1. Hubungan antara Pengetahuan dengan keikutsertaan WUS dalam pemeriksaan IVA

\begin{tabular}{lcccccccc}
\hline & \multicolumn{3}{c}{ Keikutsertaan IVA } & & $p$ \\
\cline { 2 - 8 } Pengetahuan & \multicolumn{3}{c}{ Ya } & \multicolumn{2}{c}{ Tidak } & \multicolumn{2}{c}{ Total } & \\
& \multicolumn{1}{c}{ F } & $\%$ & $\mathrm{f}$ & $\%$ & $\mathrm{f}$ & $\%$ & \\
\cline { 2 - 9 } & 25 & 52,1 & 23 & 47,9 & 48 & 100 & \\
\hline Baik & 6 & 19,4 & 25 & 80,6 & 31 & 100 & \\
Cukup Baik & & & & & & \multicolumn{2}{c}{0,010} \\
Kurang Baik & 3 & 27,3 & 8 & 72,7 & 11 & 100 & \\
\hline
\end{tabular}

Berdasarkan Tabel 1 di atas dapat diketahui bahwa WUS dengan pengetahuan baik sebagian besar mengikuti pemeriksaan IVA sebanyak 25 orang $(71,4 \%)$ dan sebagian kecil tidak mengikuti pemeriksaan IVA sebanyak 23 orang
$(47,9 \%)$. WUS dengan pengetahuan cukup baik sebagian besar tidak mengikuti pemeriksaan IVA sebanyak 25 orang $(80,6 \%)$ dan sebagian kecil mengikuti pemeriksaan IVA sebanyak 6 orang $(19,4 \%)$. WUS dengan pengetahuan kurang baik sebagian besar tidak mengikuti pemeriksaan IVA sebanyak 8 orang $(72,7 \%)$ dan sebagian kecil mengikuti pemeriksaan IVA sebanyak 3 orang $(27,3 \%)$.

Hasil analisis bivariat dengan menggunakan uji chi square diperoleh nilai $p=0,010$. Nilai $p=$ 0,010 yang lebih kecil dari $\alpha=0,05$ artinya ada hubungan pengetahuan dengan keikutsertaan WUS dalam pemeriksaan IVA di Desa Pangebatan.

Hasil penelitian ini sejalan dengan penelitian Maharse, yang menyatakan terdapat hubungan antara pengetahuan tentang kanker serviks dengan keikutsertaan ibu melakukan IVA Test di Kelurahan Jebres Surakarta. Keikutsertaan ibu melakukan IVA Test paling banyak dilakukan oleh responden dengan pengetahuan tinggi yaitu sebanyak 27 responden (66\%), dan paling sedikit dilakukan oleh responden dengan pengetahuan rendah yaitu sebanyak 5 responden $(20 \%){ }^{(8)}$

Hubungan pengetahuan dengan keikutsertaan WUS mengikuti pemeriksaan IVA dapat dijelaskan dari teori Green dalam Notoatmodjo, bahwa pengetahuan merupakan salah satu faktor presdisposisi terjadinya perilaku. Pengetahuan akan melandasi sikap yang mendorong tindakannya. ${ }^{(4)}$

Metode yang efektif untuk mendeteksi dini kanker serviks adalah pemeriksaan IVA. IVA merupakan metode skrining alternatif untuk kanker servik. Pada pemeriksaan IVA, digunakan asam 
Jurnal Kebidanan Harapan Ibu Pekalongan

asetat dengan konsentrasi 3-5\%. IVA test dilakukan dengan cara mengoleskan asam acetat 3-5 \% pada permukaan mulut rahim. Pada tahap prakanker akan timbul warna bercak putih. ${ }^{(9)}$

Setiap wanita usia subur (WUS) hendaknya termotivasi untuk melakukan tes IVA. Dorongan WUS untuk mengikuti pemeriksaan IVA untuk mendeteksi dini terjadinya kanker serviks dapat dipengaruhi oleh faktor internal, diantaranya faktor pengetahuan. Hal ini sebagaimana dinyatakan oleh Notoatmodjo, bahwa pengetahuan atau kognitif merupakan domain yang sangat penting dalam membentuk tindakan seseorang. ${ }^{(4)}$

\section{Kesimpulan}

Pengetahuan WUS tentang kanker serviks di Desa Pangebatan sebagian besar cukup baik.WUS di Desa Pangebatan sebagian besar tidak mengikuti pemeriksaan IVA.

Ada hubungan antara pengetahuan dengan keikutsertaan WUS dalam pemeriksaan IVA di Desa Pangebatan.

\section{Daftar Pustaka}

[1] Kemenkes RI. Data Informasi Kesehatan 2018. Jakarta: Kemenkes RI, 2018.

[2] IAPI. Kanker serviks di rumah sakit besar di Indonesia. 2018.

[3] Reksoprodjo. Kumpulan kuliah ilmu bedah, bagian bedah staf pengajar fakultas kedokteran Universitas Indonesia. Jakarta: Binarupa Aksar, 2013.

[4] Notoatmodjo, S. Ilmu kesehatan masyarakat. Jakarta: Rineka Cipta, 2008
[5] Santjaka, A. Biostatistik untuk praktisi kesehatan dan mahasiswa kedokteran, kesehatan lingkungan, keperawatan, kebidanan, gizi, kesehatan masyarakat. (Edisi revisi). Purwokerto: Global Internusa, 2009.

[6] Soekanto, S. Sosiologi suatu pengantar. Jakarta: PT Raja Gravindo Persada, 2006.

[7] Rahayu,Dedeh Sri. Asuhan Ibu Dengan Kanker Serviks. Jakarta: Salemba Medika, 2015.

[8] Maharse, Lesse. Hubunga npengetahuan ibu tentang kanker serviks dengan keikutsertaan ibu melakukan IVA test di Kelurahan Jebres Surakarta, 2011. [Online]. www.jurnal.stikesaisyiyah.ac.id.

[9] Wijaya D. Pembunuh ganas itu bernama kanker serviks. Yogyakarta: Sinar Kejora, 2010.

[10] Muzakkir. Dukun dan Bidan dalam Perspektif Sosiologi. Makassar: CV Sah Media, 2018.

[11] Mubarak, dkk. Ilmu Keperawatan Komunitas 1. Jakarta: Salemba Medika, 2010. 